\title{
Physicochemical Nature and Therapeutic Potential of Thermal Springs: An Overview
}

\author{
Naima Farhat ${ }^{1}$, Shabbir Hussain ${ }^{1 *}$, Khalida Nazir ${ }^{2}$ and Muhammad Riaz ${ }^{3}$ \\ ${ }^{1}$ Department of Chemistry, Lahore Garrison University, Lahore, Pakistan. \\ ${ }^{2}$ Department of Chemistry, University of Sargodha, Women Campus Faisalabad, Pakistan. \\ ${ }^{3}$ Department of Chemistry, University of Sargodha, Sargodha, Pakistan. \\ *Corresponding Author Email: dr.shabbirhussain@lgu.edu.pk \\ Received 13 June 2019, Revised 02 February 2020, Accepted 21 May 2020
}

\begin{abstract}
In this article physicochemical characteristics and therapeutic potentials of world's renowned thermal springs including Manghopir (Pakistan), Shrgalijuut (Mongolia), Ranong (Thailand), Kusatsu (Japan), Southern/Nothern part of Limpopo (South Africa), Arkansas (USA), Selangor Malaysia and Ikogosi (Nigeria) were reviewed and compared. Themal springs were characterized by flame photometery, graphite furnace atomic absorption spectroscopy, ion chromatography, inductively coupled plasma atomic emission spectroscopy, X-ray flourescent spectrometry, atomic absorption spectroscopy and titrations (argentometric, acidemetic \& complexometric). They are classified on the basis of $\mathrm{pH}$, temperature and mineral contents. The common mineral contents in these springs include $0.67-621.99 \mathrm{mg} / \mathrm{L}$ sodium, $0.67-189 \mathrm{mg} / \mathrm{L}$ potassium, $2.06-84 \mathrm{mg} / \mathrm{L}$ calcium, 0.00-56 mg/L magnesium, 0.12-12 mg/L fluorides, 0.00-982.62 mg/L chlorides, $0.15-442 \mathrm{mg} / \mathrm{L}$ sulphates and 4.3-494 mg/L bicarbonates. Their temperatures were found in the range of 26.0$90.50{ }^{\circ} \mathrm{C}$ with the $\mathrm{pH} 2.0-9.7$ and TDS value of $104.74-2188 \mathrm{mg} / \mathrm{L}$. The mineral concentration in most thermal springs is highly ideal for the treatment of numerous diseases including atopic dermatitis, psoriasis, rosacea, diabetes, rheumatoid arthritis, ankylosing spondylitis, osteoarthritis, chronic rhinosinusitis, chronic bronchitis/asthma, obesity, wounds healing and cardiovascular diseases. For curative purposes, the body is soaked in thermal waters or water may be used in the form of drinking/inhaling.
\end{abstract}

Keywords: Thermal Springs, Soaking/bathing, Nutrient's intake, Disease's Treatment

\section{Introduction}

Thermal springs release the hot water whose temperature is considerably higher as compared to that of ground water. They are generally emerged along the deep faults and fissures of earth from which the ground water is releases into the surface. Disintegration of radioactive elements, exothermic reactions and geothermal energy cause the high temperature of thermal springs. These springs are comprise of high concentration of dissolved solids and variety of minerals like alkali metals, alkaline earth metals, carbonates, bicarbonates, sulphates, trace elements and gases [1]. There are reports that thermal spring water is highly effective in the treatment of various diseases e.g., atopic dermatitis, cardiovascular diseases, inflammatory arthritis, ankylosing spondylitis, rheumatic disease, asthma and rhino sinusitis. Moreover, it is commonly believed that soaking in hot spring helps overcoming joint pains and strained muscles [2, 3]. Absorption of minerals through soaking is fractional and the amount absorbed into the body is concentration dependent [4]. The hot mineral water contains over 80 essential nutrients and minerals which are highly important for about 7000 enzymatic processes necessary for human body's 
metabolism. Many elements found in such waters possess therapeutic properties. Balneology which involves the use of natural thermal mineral water in order to treat a number of diseases, has a long history [5]. Animals are believed to discover the medicinal properties of thermal springs; they used this water to cure their feet wounds or to maintain their body temperature and hence, mankind began to explore the therapeutic properties of hot springs. In 1986, thermal springs were declared as an alternative treatment option to obtain good physical and mental health. Thus medical hydrology has been accepted as complementary medicine and an emerging new discipline by World Health Organization [6].

Though the thermal springs are natural sources of important nutrients and minerals for balneotherapy, however, reported studies also suggest that they may also contain toxic elements such as arsenic and mercury so care should be exercised regarding appropriate and precise use of thermal springs [7]. The presence of metal contents in balanced amounts is compulsory as their exceeding concentration in water may also lead to environmental issues [8-11].

Keeping in view the use of thermal springs for curative purposes, the physicochemical characteristics and therapeutic potentials of thermal springs of World's renowned thermal springs e.g., Manghopir (Pakistan) [12], Shrgalijuut (Mongolia) [13], Ranong (Thailand) [14], Kusatsu (Japan) [15], North and Southern Part of Limpopo (South Africa) [7, 16], Arkansas (USA) [17], Selangor (Malaysia) [18] and Ikogosi (Nigeria) [19] are reviewed in this article. Table 1 displays the brief geology, sampling and methodology of the investigated springs.

Table 1. Brief geology, sampling and methodology of the investigated springs.

\begin{tabular}{|c|c|c|c|}
\hline Springs & Sampling & Geographic location and geology & References \\
\hline $\begin{array}{l}\text { Manghopir } \\
\text { (Pakistan) }\end{array}$ & $\begin{array}{l}26 \text { samples from } \\
\text { different sites (closed } \\
\text { bath and open bath) }\end{array}$ & 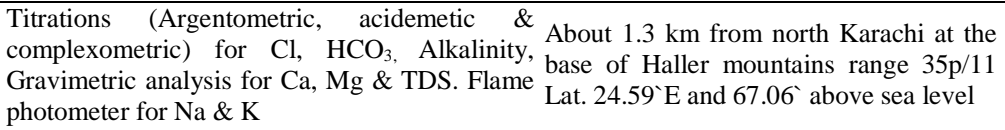 & [12] \\
\hline $\begin{array}{l}\text { Shargalijuut } \\
\text { (Mangolia) }\end{array}$ & $\begin{array}{l}23 \text { samples were } \\
\text { collected from the } \\
\text { said spring }\end{array}$ & $\begin{array}{l}\text { Digital instruments for } \mathrm{pH} \text {, Temp } \\
\text { and conductivity. } \mathrm{Na} \text { and } \mathrm{K} \text { by inductively city; spring covers the banks of the river } \\
\text { coupled plasma optical spectrometry, } \mathrm{Ca} \text { and between the peaks Myangan Ugalzat Uul } \\
\mathrm{Mg} \text { by Trilon-Bititratin method, Argentometric, }(3483 \mathrm{~m}) \text { and shargalijuut Uul }(3137 \mathrm{~m}) \text { in } \\
\text { Acidematic titrations for } \mathrm{HCO}_{3}, \mathrm{Cl}, \mathrm{SO}_{4} \\
\text { the Gobi region }\end{array}$ & [13] \\
\hline $\begin{array}{l}\text { Ranong } \\
\text { (Thailand) }\end{array}$ & $\begin{array}{l}\text { Samples were } \\
\text { collected from two } \\
\text { hot spring Rashwani } \\
\text { (father well) \& Porn } \\
\text { rang }\end{array}$ & $\begin{array}{l}\text { TDS by titration } \mathrm{K}, \mathrm{Ca}, \mathrm{Mg}, \mathrm{Na}, \mathrm{F}, \mathrm{Cl}, \mathrm{SO}_{4}, 2 \mathrm{~km} \text { east of Ronong town, porn-rang, } \\
\mathrm{HCO}_{3} \text { by chromatographic technique, } \mathrm{Fe}, \mathrm{Mn} \mathrm{Pb} \text { hotspring located in Ngao national park } \\
\text { by graphite furnace atomic absorption } \begin{array}{l}\text { and far larger than rashwani hot string } \\
\text { spectroscopy }\end{array}\end{array}$ & {$[14]$} \\
\hline $\begin{array}{l}\text { Kusatsu Onsen } \\
\text { (Japan) }\end{array}$ & $\begin{array}{l}\text { Samples collected } \\
\text { from } 6 \text { major hot } \\
\text { springs in the Kusatsu } \\
\text { hot springs }\end{array}$ & $\begin{array}{l}\text { Flame emission spectroscopy (FE), inductively Located at the eastern foot of Kasatsu- } \\
\text { coupled plasma atomic emission spectroscopy } \\
\text { (ICP-AES) and ion chromatography }\end{array}$ & {$[15]$} \\
\hline $\begin{array}{l}\text { Limpopo North } \\
\& \text { South } \\
\text { (Africa) }\end{array}$ & $\begin{array}{l}5 \text { samples (southern } \\
\text { part) } 8 \text { samples (from } \\
\text { northern part) }\end{array}$ & $\begin{array}{ll} & \text { Includes various lithologies, Goud plaats- } \\
\text { Chemical analysis conducted by institute } & \text { of Hot river Gneiss suite and Beit Bridge } \\
\text { water, climate and soil (ARC, Pretoria ) } & \text { complex. Surface geology indicated as } \\
& \text { quartzite, shall and red shally sand stone. }\end{array}$ & {$[7,16]$} \\
\hline $\begin{array}{l}\text { Arkansas } \\
\text { (USA) }\end{array}$ & $\begin{array}{l}\text { Sample were colleted } \\
\text { from all the hot spring } \\
\text { area }\end{array}$ & $\begin{array}{ll}\text { Gravimetric analysis was done for all ions } & \begin{array}{l}\text { miles east of the Oklahoma line. } 500 \text { feet } \\
\text { above sea level and lies at the easterly } \\
\text { base of the mountain complex Ouachita } \\
\text { range }\end{array}\end{array}$ & {$[17]$} \\
\hline $\begin{array}{l}\text { Selangor } \\
\text { (Malaysia) }\end{array}$ & $\begin{array}{l}\text { Samples were } \\
\text { collected from } 11 \text { hot } \\
\text { springs }\end{array}$ & 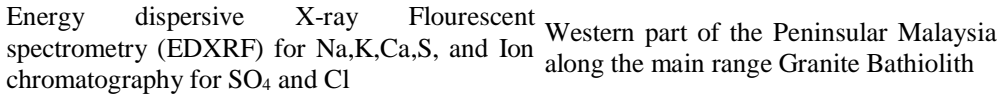 & [18] \\
\hline $\begin{array}{l}\text { Ikogosi } \\
\text { (Nigeria) }\end{array}$ & $\begin{array}{l}\text { Samples collected } \\
\text { from (OOzing point } \\
\text { of warm and cold } \\
\text { springs and their } \\
\text { mixing point }\end{array}$ & $\begin{array}{ll}\text { TDS by gravimetric analysis, } \mathrm{Na}, \mathrm{K}, \mathrm{Mg}, \mathrm{Ca} \text { by Its underlain by a group of slightly } \\
\text { migmatised to non-migmatised para- } \\
\text { Alpha } 4 \text { Atomic Absorption Spectrometer other } \\
\text { ions analysed by standard procedures } & \text { quartz and meta-igneous rocks (quartized } \\
& \text { qualites). }\end{array}$ & [19] \\
\hline
\end{tabular}


Numerous studies involving the patients and Murine models were also reviewed for the treatment of diseases including atopic dermatitis [20-22], psoriasis [23-25], rosacea [26], diabetes [27, 28], rheumatoid arthritis [29], ankylosing spondylitis [30], osteoarthritis [31-33], chronic rhinosinusitis [34], chronic bronchitis/ asthma [35, 36], obesity [37], wound healing [3] and cardiovascular diseases [38, 39]. Other literature consulted include that of physical and chemical nature $[2,4-7,14,16,40-50]$, geological influence on chemical composition [7, $16,51]$, classification of thermal springs $[6,40]$, ways of using the thermal mineral water for curative purposes [52-57] and therapeutic potential of thermal springs [58-65].

\section{Physical and chemical nature of thermal springs}

The physicochemical properties of world's eight renowned thermal springs are given in Table 2.The temperature and $\mathrm{pH}$ lies in the ranges of $26-90.50{ }^{\circ} \mathrm{C}$ and $2.0-9.7$, respectively; the total dissolved solids lie between 104.74 and 2188 $\mathrm{mg} / \mathrm{L}$, but most thermal springs contain their values less than $400 \mathrm{mg} / \mathrm{L}$. Common cations present in thermal water include $\mathrm{K}^{+}, \mathrm{Na}^{+}, \mathrm{Mg}^{+2}$ and $\mathrm{Ca}^{+2}$. The magnesium $(\mathrm{Mg})$, calcium $(\mathrm{Ca})$, potassium $(\mathrm{K})$ and sodium $(\mathrm{Na})$ contents lie in the ranges of $0.00-56 \mathrm{mg} / \mathrm{L}, 2.06-84 \mathrm{mg} / \mathrm{L}, 0.67-189$ $\mathrm{mg} / \mathrm{L}$ and $0.67-621.99 \mathrm{mg} / \mathrm{L}$, respectively. Anions present in hot springs include $\mathrm{Cl}^{-}, \mathrm{SO}_{4}{ }^{-2}$ and $\mathrm{HCO}_{3}{ }^{-}$ with their concentrations in the ranges of 0.00 $982.62 \mathrm{mg} / \mathrm{L}, 0.15-442 \mathrm{mg} / \mathrm{L}$ and $4.3-494 \mathrm{mg} / \mathrm{L}$, respectively. Most of the thermal springs do not have fluoride ions; however, some thermal springs contain the $\mathrm{F}^{-}$ions in range of $0.00-11 \mathrm{mg} / \mathrm{L}$. Fluorides are present in less amount than $\mathrm{Cl}^{-}, \mathrm{SO}_{4}{ }^{-2}$ and $\mathrm{HCO}_{3}{ }^{-}$in most of the thermal springs. Trace elements found in hot/thermal springs include majorly zinc $(\mathrm{Zn})$, iron $(\mathrm{Fe})$, strontium $(\mathrm{Sr})$, lithium (Li), selenium (Se), bromide $\left(\mathrm{Br}^{-}\right)$and iodide ( $\left.\mathrm{I}^{-}\right)$ions. The gases such as $\mathrm{H}_{2} \mathrm{~S}, \mathrm{NH}_{3}, \mathrm{He}$, $\mathrm{Ne}$ and $\mathrm{Rn}$ are also reported in hot/thermal springs $[2,4-7,14,16,40-50]$.

Table 2. Physical and chemical properties of world's eight renowned thermal springs regions.

\begin{tabular}{|c|c|c|c|c|c|c|c|c|c|}
\hline & $\begin{array}{l}\text { Mongopir } \\
\text { (Pakistan) }\end{array}$ & $\begin{array}{l}\text { Shrgalijuut } \\
\text { (Mongolia) }\end{array}$ & $\begin{array}{c}\text { Ranong } \\
\text { (Thailand) }\end{array}$ & $\begin{array}{c}\text { Kusatsu } \\
\text { (Japan) }\end{array}$ & $\begin{array}{c}\text { Southern Part } \\
{[7]} \\
\end{array}$ & \begin{tabular}{|c}
$\begin{array}{c}\text { Northern Part } \\
{[16]}\end{array}$ \\
\end{tabular} & \multirow{2}{*}{$\begin{array}{c}\text { Arkansas } \\
\text { (USA) } \\
{[17]}\end{array}$} & \multirow{2}{*}{$\begin{array}{c}\text { Selangor } \\
\text { (Malaysia) } \\
{[18]}\end{array}$} & \multirow{2}{*}{$\begin{array}{c}\text { Ikogos } \\
\text { (Nigeria) } \\
\text { [19] }\end{array}$} \\
\hline & & & & & \multicolumn{2}{|c|}{ Limpopo (South Africa) } & & & \\
\hline Temp* $\left(\mathrm{C}^{\circ}\right)$ & 47 & $50-90.50$ & $61-65.3$ & $60-67$ & $40-60$ & $26-67.5$ & $32-62$ & $36.7-67.9$ & $35.20-37.0$ \\
\hline $\mathrm{pH}$ & $7.2-7.6$ & $8.2-9.7$ & $7.56-7.74$ & 2 & $6-9$ & $7.35-9.70$ & $4.52-7.70$ & $7.14-8.98$ & $6.1-7$ \\
\hline $\begin{array}{l}\text { TDS } \\
(\mathrm{mg} / \mathrm{L})\end{array}$ & $2180-2188$ & - & $210-230$ & - & $<450$ & $104.74-1385$ & $>400$ & $225-376$ & $170-514$ \\
\hline \multicolumn{10}{|c|}{ Cations ( mg/L) } \\
\hline Sodium & $544-555$ & $62.5-105$ & $10.2-13.8$ & 53.7 & $21.98-151.6$ & $10.59-621.99$ & 4 & $33.68-81.91$ & $0.67-0.71$ \\
\hline Potassium & $21-25$ & $1.3-1.9$ & $150-189$ & 16 & $2.9-6.13$ & $0.99-21.79$ & 1.5 & $1.47-56.81$ & $0.67-0.84$ \\
\hline Calcium & $80-84$ & $1.8-7.2$ & $18.7-20.6$ & 72 & $13-36.13$ & $1.31-79.37$ & 45 & $2.44-19.77$ & $2.06-2.67$ \\
\hline Magnesium & 56 & $0.4-0.5$ & $0.36-0.51$ & 39 & $1.8-6.44$ & $0.00-27.60$ & 4.8 & - & $4.22-4.32$ \\
\hline \multicolumn{10}{|c|}{ Anions (mg/L) } \\
\hline Fluoride & - & $0.00-1.37$ & $0.12-0.89$ & 12 & $0.95-11$ & $0.18-6.50$ & 0.2 & - & - \\
\hline Chloride & $584-599$ & $13-26$ & $18.3-23.2$ & 343 & $2.21-138.5$ & $19.43-982.62$ & 1.8 & $7.06-20.66$ & $0-0.004$ \\
\hline Sulphate & $437-442$ & $25-66$ & $8.1-12.1$ & 611 & $2.16-92.82$ & $2.98-226.00$ & 8 & $0.15-1.51$ & $30-81$ \\
\hline Bicarbonate & $395-494$ & $97-170$ & $4.3-5.7$ & - & $102-213.5$ & - & 165 & - & $35-51.5$ \\
\hline
\end{tabular}

Temp* $=$ Temperature 


\section{Geological influence on chemical composition}

The origin of hot springs is owed to the local presence of deep geological structures such as faults, folds, fractures, and dykes providing means of circulation to depth and return of heated water to surface. The amount of dissolved salts, nutrients and trace elements found in thermal waters are dependent on regional differences in climate, geology, soil and vegetation [7]. The less saline water comes out from crystalline rocks where as the saline water is found to be associated with sedimentary rocks [16]. The physicochemical nature of hot water depends on mixing with fresh precipitation, rock or water interaction in deep formations, residence time of hot water in migration pathway, migration depth, composition of infiltrating solution etc [51].

\section{Classification of thermal springs}

Thermal springs are classified on the basis of temperature, $\mathrm{pH}$ and dry waste $[6,40]$.

1. There are three types of thermal springs according to temperature:

(i) Hypothermal springs: The temperature ranges from 20 to $30^{\circ} \mathrm{C}$ in these thermal springs.

(ii) Thermal springs: The temperature of these thermal springs is in the range of 30 to $50^{\circ} \mathrm{C}$.

(iii) Hyper-thermal springs: The temperature of these thermal springs is above $50^{\circ} \mathrm{C}$.

2. The thermal water is classified on the basis of $\mathrm{pH}$ into six classes:

(i) Alkaline springs $9 \leq \mathrm{pH}$

(ii) Weak alkaline springs $7.5 \leq \mathrm{pH}<9$

(iii) Neutral springs $6 \leq \mathrm{pH}<7.5$

(iv) Weak acid springs $4 \leq \mathrm{pH}<6$

(v) Acid springs $2 \leq \mathrm{pH}<4$

(vi) Strong acid springs $\mathrm{pH}<2$

3. Hot springs may be classified into following three categories depending upon their dry waste material:

(i) Minerals from 1-1.5 g/L (ii) Middle minerals from 0.2- $1.0 \mathrm{~g} / \mathrm{L}$

(iii) Oligo minerals less than $0.2 \mathrm{~g} / \mathrm{L}$

Ways of using the thermal mineral water for curative purposes

For the therapeutic purposes, the thermal/hot mineral waters can be used internally or externally. The important ways of using the thermal/hot minerals waters are as follows:

\section{Balneotherapy}

The immersion of the body (except head) or body parts into the water for the treatment and cure of diseases is called bathing or soaking [52]. The minerals and other substances in the water are transferred to the skin and blood streams through the process of osmosis [53]. The osmotic pressure, mineral concentration, $\mathrm{pH}$, the nature/amount of mineral contents [54], fat/water solubility due to structure of membrane and fluid condition of the individual [55] affect the osmotic transfer and the movement of minerals into the body. Medical balneotherapists have noted that even small amounts of therapeutic minerals absorbed into the body through skin have a significant therapeutic value [56].

\section{Hydropenia (mineral water drinking cure)}

Ingestion of mineral water is another treatment method which aimed at modification of metabolic activities, gastro-intestinal, renal and urodynamic functions. The mineral water can also be taken as a substitute for drinking and supplementation of minerals.

\section{Inhalation}

Mineral waters and some other natural gases present in thermal/hot springs (mainly radon) are used via the respiratory tract. It has beneficial effects on the respiratory functions and mucosa of respiratory tract. After inhalation substances get absorbed and induce systemic effects [57]. 
Pak. J. Anal. Environ. Chem. Vol. 21, No. 1 (2020)

Therapeutic potential of thermal springs

Table 3. Studies reported on therapeutical potential of thermal springs.

\begin{tabular}{|c|c|c|c|c|c|c|}
\hline Subject & $\begin{array}{c}\text { Water } \\
\text { Classification } \\
\end{array}$ & Pathology & $\begin{array}{l}\text { Mode of } \\
\text { Therapy }\end{array}$ & $\begin{array}{c}\text { Treatment } \\
\text { Duration }\end{array}$ & Results & References \\
\hline Murine model & $\mathrm{Na}-\mathrm{HCO}_{3}$ & & Balneotherapy & $\begin{array}{l}5 \text { mins daily for } \\
\text { one week }\end{array}$ & Effective and safe & {$[20]$} \\
\hline 70 patients & $\begin{array}{l}\text { Acidic plus Mn } 1.4 \\
\mathrm{mg} / \mathrm{L}, \mathrm{I} 0.3 \mathrm{mg} / \mathrm{L}\end{array}$ & $\begin{array}{c}\text { Atopic } \\
\text { dermatitis }\end{array}$ & Balneotherapy & $\begin{array}{l}10 \text { mins twice } \\
\text { daily for two } \\
\text { months }\end{array}$ & $\begin{array}{l}\text { Useful for controlling the } \\
\text { skin symptoms of acute flares of } \mathrm{AD}\end{array}$ & {$[21]$} \\
\hline 104 children & $\begin{array}{l}\mathrm{Na} \text { and } \mathrm{Mg} \text { rich } \\
\text { water }\end{array}$ & & Balneotherapy & $\begin{array}{l}\text { Once daily } \\
(20 \text { min) for } 2 \\
\text { weeks }\end{array}$ & Effective for mild to moderate AD & {$[22]$} \\
\hline $\begin{array}{l}\text { Murine model } \\
\text { (Oxazolone indu } \\
\text { ced mice) }\end{array}$ & Sulphurous mineral & & Balneotherapy & $\begin{array}{l}20 \min \times 2 / \text { day } \\
\text { for } 3 \text { weeks }\end{array}$ & $\begin{array}{l}\text { Somatostatin plasma concentration was } \\
\text { increased. Significant reduction in PASI } \\
\text { score }\end{array}$ & {$[23]$} \\
\hline $\begin{array}{l}71 \text { adult patients } \\
\text { with PASI score } \\
\text { greater than } 10\end{array}$ & $\begin{array}{l}\text { Sodium and } \\
\text { magnesium rich } \\
\text { water }\end{array}$ & Psoriasis & Balneotherapy & 3 weeks & $\begin{array}{l}\text { Minor therapeutic effects with saline spa } \\
\text { water alone, and no beneficial effect of } \\
\text { bathing to enhance phototherapy }\end{array}$ & {$[24]$} \\
\hline $\begin{array}{l}\text { Patients with } \\
\text { mild to severe } \\
\text { psoriasis }\end{array}$ & Selenium rich water & & $\begin{array}{l}\text { Immersion } \\
\text { and drinking }\end{array}$ & 3 weeks & Improvement in psoriatic plaques & {$[25]$} \\
\hline Patients & $\begin{array}{l}\mathrm{Na}, \mathrm{Ca} \text {, sulphate bi- } \\
\text { carbonate and } \\
\text { fluoride }\end{array}$ & Rosacea & Balneotherapy & 3 weeks & $\begin{array}{l}\text { Significant down regulation of TNF } \alpha, \mathrm{IL}- \\
1 \alpha \text { and VEGF gene expression. Benefits } \\
\text { observed in rosacea and psoriasis }\end{array}$ & {$[26]$} \\
\hline $\begin{array}{l}\text { Murine Model } \\
\text { (alloxan induced } \\
\text { diabetic rats) }\end{array}$ & $\begin{array}{l}\text { Sulphurous and alk } \\
\text { aline water Andrade } \\
\text { junior }\end{array}$ & & Ingestion & 3 weeks & $\begin{array}{l}\text { Reversed the hyperglycemic state and } \\
\text { improved SOD synthesis. Beneficial } \\
\text { effects for diabetics }\end{array}$ & {$[27]$} \\
\hline $\begin{array}{l}35 \text { patients }(46- \\
74 \text { years old) }\end{array}$ & $\begin{array}{c}\text { Sulphurous- } \\
\text { bicarbonated- } \\
\text { calcic- } \\
\text { magnesian mineral } \\
\text { water }\end{array}$ & Diabetes & Ingestion & $\begin{array}{l}375 \mathrm{~mL} / \text { day } 14 \\
\text { days }\end{array}$ & $\begin{array}{l}\text { Reduction blood glycaemia } \\
\text { levels. Effective for type- } 2 \text { diabetes. }\end{array}$ & {$[28]$} \\
\hline 41 patients & $\begin{array}{l}\text { Rich in sodium } \\
\text { chloride and sulfate }\end{array}$ & $\begin{array}{l}\text { Rheumatoid } \\
\text { arthritis }\end{array}$ & $\begin{array}{l}\text { Mineral water } \\
\text { baths and } \\
\text { mud packs }\end{array}$ & 2 weeks & $\begin{array}{l}\text { Temporary improvement in } \\
\text { clinical indices }\end{array}$ & [29] \\
\hline 14 patients & $\begin{array}{l}\text { Mineral water }(\mathrm{Na} \\
\mathrm{Ca}, \mathrm{Mg}, \mathrm{Cl}, \mathrm{SO}_{4} \\
\left.\mathrm{HCO}_{3}\right)\end{array}$ & $\begin{array}{l}\text { Ankylosing } \\
\text { spondylitis }\end{array}$ & $\begin{array}{l}\text { Balneotherapy } \\
\text { and mud } \\
\text { packs }\end{array}$ & 2 weeks & $\begin{array}{l}\text { Improvement in morning stiffness and } \\
\text { significant reduction in the use of } \\
\text { analgesics and NSAIDs }\end{array}$ & {$[30]$} \\
\hline $\begin{array}{l}\text { Murine model } \\
\text { (Wistar rats) }\end{array}$ & $\begin{array}{l}\text { Sulfurous rich } \\
\text { water }\end{array}$ & & Balneotherapy & & $\begin{array}{l}\text { Reduced cartilage destruction and } \\
\text { oxidative damage }\end{array}$ & [31] \\
\hline $\begin{array}{l}46 \text { patients }(57 \\
\text { to } 85 \text { years old })\end{array}$ & $\begin{array}{l}\text { Sodium-bicarbonate } \\
\text { with fluoride and } \\
\text { chloride ions }\end{array}$ & $\begin{array}{l}\text { Osteoar- } \\
\text { thritis }\end{array}$ & Balneotherapy & $\begin{array}{c}3 \text { weeks } \\
20 \mathrm{~min} / \text { day }\end{array}$ & Effective in advanced knee arthritis & [32] \\
\hline $\begin{array}{l}\text { Murine Model } \\
\text { (Old female } \\
\text { NMRI mice) }\end{array}$ & $\begin{array}{l}\mathrm{Na}, \mathrm{K}, \mathrm{Mg}, \text { bi- } \\
\text { carbonates sulphate } \\
\text { and } \mathrm{H}_{2} \mathrm{~S}\end{array}$ & & Balneotherapy & $\begin{array}{l}30 \mathrm{~min} / \text { day for } \\
12 \text { to } 16 \text { weeks }\end{array}$ & $\begin{array}{l}\text { Found effective as anti-inflammatory and } \\
\text { analgesic }\end{array}$ & [33] \\
\hline $\begin{array}{l}80 \text { patients with } \\
\text { CRS }\end{array}$ & $\begin{array}{l}\text { Sulphurous mineral } \\
\text { with } \mathrm{Na}, \mathrm{Ca} \text {, } \\
\mathrm{Mg} \text {, chlorides, nitrat } \\
\text { es and } \mathrm{H}_{2} \mathrm{~S}\end{array}$ & $\begin{array}{l}\text { Chronic } \\
\text { rhinosin- } \\
\text { usitis }\end{array}$ & $\begin{array}{c}\text { Warm vapors } \\
\text { inhalation and } \\
\text { nasal } \\
\text { irrigations }\end{array}$ & $\begin{array}{l}12 \text { days to } 3 \\
\text { months }\end{array}$ & $\begin{array}{l}\text { Significant reduction in Serum } \\
\text { concentration of } \operatorname{IgE} \text {, effective for CRS }\end{array}$ & [34] \\
\hline 39 patients & salt-bromide-iodine & $\begin{array}{l}\text { Chronic } \\
\text { bronchitis / }\end{array}$ & Inhalation & 2 weeks & $\begin{array}{l}\text { Reduces proportion of neutrophils in } \\
\text { induced sputum, may have mild anti- } \\
\text { inflammatory effect on the airways }\end{array}$ & {$[35]$} \\
\hline $\begin{array}{l}\text { Heavy smokers } \\
(50-75 \text { years } \\
\text { old })\end{array}$ & $\begin{array}{l}\text { Sulphurous mineral } \\
\text { water }\end{array}$ & asthma & Inhalation & 10 days & $\begin{array}{l}\text { Reduction of NO shows anti- } \\
\text { inflammatory effect }\end{array}$ & [36] \\
\hline $\begin{array}{l}50 \\
\text { women (average } \\
\text { age } 35)\end{array}$ & $\begin{array}{l}\text { Borebole } \\
\text { (klaipeda region) } \\
\mathrm{Na}, \mathrm{Ca} \text {, Sulphate } \\
\text { and bicarbonate }\end{array}$ & Obesity & Balneotherapy & $\begin{array}{l}15-20 \text { min, } 5 \\
\text { times/ week, for } 3 \\
\text { weeks }\end{array}$ & $\begin{array}{l}\text { Improvement in skin condition and } \\
\text { reduction of hypodermic body fat content }\end{array}$ & [37] \\
\hline $\begin{array}{l}\text { Murine model } \\
\text { (100 male rats) }\end{array}$ & $\begin{array}{l}\text { Calcic-magnesic- } \\
\text { sulphate mineral }\end{array}$ & Cardiova- & Ingestion & 120 days & $\begin{array}{l}\text { Regulating the enzymes responsible for } \\
\text { bile acid and cholesterol metabolism }\end{array}$ & [38] \\
\hline $\begin{array}{l}12 \text { Hypercholester } \\
\text { olemic patients }\end{array}$ & $\begin{array}{l}\text { Bicarbonate-rich } \\
\text { water }\end{array}$ & & Ingestion & $\begin{array}{l}1.25 \text { Liters for } 8 \\
\text { weeks }\end{array}$ & $\begin{array}{l}\text { Decrease in basal TG and VLDLTG and } \\
\text { VLDL cholesterol. Effective for } \\
\text { hypercholesterolemia }\end{array}$ & [39] \\
\hline $\begin{array}{l}\text { Murine Model } \\
9 \text { Nude rats) }\end{array}$ & $\begin{array}{l}\text { Carbonated with } \\
\text { sodium }\left(42^{\circ} \mathrm{C}\right)\end{array}$ & $\begin{array}{l}\text { Wound } \\
\text { healing }\end{array}$ & $\begin{array}{l}\text { Bathing at } \\
42^{\circ} \mathrm{C}\end{array}$ & $\begin{array}{l}15 \text { min every three } \\
\text { days for } 8 \text { weeks }\end{array}$ & $\begin{array}{l}\text { Increase vessel density and reduced } \\
\text { inflammatory cells of wound area }\end{array}$ & [3] \\
\hline
\end{tabular}




\section{Bicarbonate mineral water}

Bicarbonate natural mineral waters are alkaline with small amount of minerals having diuretic characteristics. The bicarbonate minerals have positive effects on digestive tract and play a vital role in the prevention of cardiovascular diseases [58].

\section{Sulphurous mineral waters}

Sulphurous mineral water is abundant in hydrogen sulphite $\left(\mathrm{HSO}_{3}{ }^{-}\right.$) and possesses the ability to cure internal organ disorders e.g., ischemia, adverse affects on kidney and nervous system and high blood pressure [58, 59]. Sulphurous mineral waters contain beneficial antipruritic and anti-inflammatory keratoplastic effects [60]. Its anti-fungal and bactericidal effects have enabled its applications in the treatment of tinea carports, infected leg ulcers, tinea versicolor, tinia capitis and tinia corporis. Sulphurous bathing has been considered useful for immunomediated conditions including atopic dermatitis and contact dermatitis psoriasis. It was recently concluded that the sulphurous minerals water can play a pivotal role in immune-regulation in the skin [61].

\section{Salt mineral waters}

Chlorides are often found in combination with sodium and are the main constituents of "salt mineral waters". Such waters from mineral thermal springs are particularly valued and believed to improve the joint movements, muscle strengthening and improve/maintain functional mobility. Well known for its anti-inflammatory effects, it is also applied to treat successfully a variety of pathological conditions, such as issues of gastrointestinal system [61-65].

\section{Calcic mineral waters}

Calcium along with the bicarbonate content maintains an alkaline environment and helps in improving the acid-base balance in blood. The positive effects of calcium-rich mineral waters on bone mineralization have been verified [58].

\section{Magnesia mineral waters}

Such waters are characterized by the presence of magnesium as an essential ingredient. The presence of magnesium with sulphate, bicarbonate and calcium minerals in waters can induce the therapeutic activity in functional disorders of biliary tract. High range of magnesium is important for oddi sphincter relaxation and allows the bile flowing and also supports biliary ducts activity [58].

\section{Conclusion}

Thermal springs are the natural sources of many minerals depending on the geographical and geological conditions of the region and site. They are classified on the basis of $\mathrm{pH}$, temperature and mineral contents. Presence of more than 80 essential nutrients and minerals in thermal springs enables them to possess therapeutic potential and makes them highly ideal for the treatment of numerous diseases including atopic dermatitis, psoriasis, rosacea, diabetes, rheumatoid arthritis, ankylosing spondylitis, osteoarthritis, chronic rhinosinusitis, chronic bronchitis/asthma, obesity, wounds healing and cardiovascular diseases. For curative purposes, the body is soaked in thermal waters or water may be used in the form of drinking/inhaling. The investigations on world's renowned thermal springs including Monghopir (Pakistan), Shargali Juul (Mongolia), Ranong (Thailand), Kusatsu (Japan), Southern/Nothern part of Limpopo (South Africa), Arkansas (USA), Selangor (Malaysia) and Ikogosi (Nigeria) contain 4-621 mg/L sodium, 0.99-189 $\mathrm{mg} / \mathrm{L}$ potassium, 0.3-84 $\mathrm{mg} / \mathrm{L}$ calcium, $0.00-56 \mathrm{mg} / \mathrm{L}$ magnesium, $0.00-11 \mathrm{mg} / \mathrm{L}$ fluorides, $0.00-982 \mathrm{mg} / \mathrm{L}$ chlorides, $0.00-442 \mathrm{mg} / \mathrm{L}$ sulphates and 10-494 $\mathrm{mg} / \mathrm{L}$ bicarbonates. Their temperatures were found in the range of $32.0-90.5{ }^{\circ} \mathrm{C}$ with the $\mathrm{pH} 2.0-9.7$ and TDS value of $104.74-1857 \mathrm{mg} / \mathrm{L}$. Thermal springs classified on the basis of $\mathrm{pH}$, temperature and mineral contents.

\section{References}

1. S. Mohanty, A. Mahanty, R. P. Yadav, G. K. Purohit, B.N. Mohanty and B. P. Mohanty, Int. J. Geo. Earth Env. Sci., 4 (2014) 85. https://www.cibtech.org/jgee.htm 
2. O. H. Lele and P. V. Deshmukh, Int. J. Appl. Res., 2 (2016) 427.

http://www.allresearchjournal.com/archives/ ?year $=2016 \&$ vol $=2 \&$ issue $=5 \&$ part $=\mathrm{G} \&$ Arti cleId $=1944$

3. J. Liang, D. Kang, Y. Wang, Y. Yu, J. Fan and E. Takashi, PLoS One, 10 (2015) 1. https://doi.org/10.1371/journal.pone.011710 $\underline{6}$

4. H. W. Lopez, F. Leenhardt, C. Coudray and C. Remesy, Int. J. Food Sci. Tech., 37 (2002) 727.

https://doi.org/10.1046/j.1365-

2621.2002.00618.x

5. A. P. Verhagen, S. M. Bierma-Zeinstra, J. Cardoso, R. De Bie, M. Boers and H. De Vet, Cochrane Database Syst Rev., 1 (2015). 10.1002/14651858.CD000518.pub2

6. J. M. Reyes, A. O. Soriano, M. E. Jaramillo and I. V. Romero, Int. J. Res. Innov. Earth Sci., 2 (2015) 10.

https://www.ijries.org/administrator/compon ents/com_iresearch/files/publications/IJRIE

S-48_final.pdf

7. J. Olivier, H. Van Niekerk and I. Van der Walt, Water SA, 34 (2008) 163.

https://doi.org/10.4314/wsa.v34i2.183636

8. H. Ullah, S. Hussain and A. Ahmad, Int. J. Econ. Env. Geol., 10 (2019) 72.

https://www.econ-environgeol.org/index.php/ojs/article/view/265

9. M. Chaudhari, S. Hussain, H. Rehman and T. G. Shahzady, Int. J. Econ. Env. Geol., 10 (2019) 70.

https://www.econ-environ-

geol.org/index.php/ojs/article/view/311

10. M. Iqbal, M. Muneer, S. Hussain, B. Parveen, M. Javed, H. Rehman, M. Waqas and M. A. Abid, Pol. J. Env. Stud., 28 (2019) 1.

https://doi.org/10.15244/pjoes/92706

11. H. Rehman, Z. Ali, M. Hussain, S. R. Gilani, T. G. Shahzady, A. Zahra, S. Hussain, H. Hussain, I. Hussain and M.U. Farooq, Dig. J. Nanomater. Biostruct., 14 (2019) 1033.

http://www.chalcogen.ro/index.php/journals/ digest-journal-of-nanomaterials-andbiostructures/8-djnb/495-volume-14number-4-october-december-2019
12. A. Javed, J. Iqbal, U. Asghar, F. A. Khan, A. B. Munshi and I. Sddiqui, J. Chem. Soc. Pak., 31 (2009) 396. https://jcsp.org.pk/ArticleUpload/380-14831-CE.pdf

13. G. Bignall, B. Batkhishig and N. Tsuchiya, Geotherm. Resour. Council Transact., 28 (2004) 449.

14. Y. Sudjaroen, K. Thongkao and K. Suwannahong, Ann. Trop. Med. Public Health, 10 (2017) 366. https://doi.org/10.4103/1755-6783.196588

15. Y. Kikawada, S. Kawai, K. Shimada and T. Oi, J. Disaster Res., 3 (2008) 261. https://doi.org/10.20965/jdr.2008.p0261

16. J. Olivier, J. Venter and C. Jonker, Water SA, 37 (2011) 427. https://doi.org/10.4314/wsa.v37i4.1

17. J. K. Haywood, Analyses of the Waters of the Hot Springs of Arkansas, US Government Printing Office, 1912.

18. Z. Hamzah, N. L. A. Rani, A. Saat and A. K. Wood, Malay. J. Anal. Sci., 17 (2013) 436. http://pkukmweb.ukm.my/ mjas/

19. A. A. Oladipo, E. Oluyemi, I. Tubosun, M. Fasisi and F. Ibitoye, J. Appli. Sci., 5 (2005) 75. doi: 10.3923/jas.2005.75.79

20. Y. B. Lee, S. J. Kim, S. M. Park, K. H. Lee, H. J. Han, D. S. Yu, S. Y. Woo, S. T. Yun, S.-Y. Hamm and H. J. Kim, Ann. Dermatol., 28 (2016) 192.

https://doi.org/10.5021/ad.2016.28.2.192

21. K. Kubota, I. Machida, K. Tamura, H. Take, H. Kurabayashi, T. Akiba and J. Tamura, Acta Derm. Venereol., 77 (1997) 452. doi: 10.2340/0001555577452454

22. S. Farina, P. Gisondi, M. Zanoni, M. Pace, L. Rizzoli, E. Baldo and G. Girolomoni, $J$. Dermatol. Treat., 22 (2011) 366.

https://doi.org/10.3109/09546634.2010.5129 $\underline{50}$

23. M. Boros, Á. Kemény, B. Sebők, T. Bagoly, A. Perkecz, Z. Petőházi, G. Maász, J. Schmidt, L. Márk and T. László, Eur. J. Integ. Med., 5 (2013) 109. https://doi.org/10.1016/j.eujim.2012.09.005

24. C. Léauté-Labreze, F. Saillour, G. Chêne, C. Cazenave, M. -L. Luxey-Bellocq, C. Sanciaume, J. F. Toussaint and A. Taïeb, Arch. Dermatol., 137 (2001) 1035. 
doi:10-1001/pubs.Arch Dermatol.-ISSN0003-987x-137-8-dst00117

25. J. Pinton, H. Friden, N. Kettaneh - Wold, S. Wold, B. Dreno, A. Richard and T. Bieber, Br. J. Dermatol., 133 (1995) 344. https://doi.org/10.1111/j.13652133.1995.tb02657.x

26. M. Z. Karagülle, M. Karagülle, S. Kılıç, H. Sevinç, C. Dündar and M. Türkoğlu, Int. J. Biometeorol., 62 (2018) 1657. https://doi.org/10.1007/s00484-018-1565-8

27. A. C. Honorio-França, F. C. De Oliveira, E. L. França and C. K. Ferrari, Nutr. Clín. Diet. Hosp., 35 (2015) 50. 5 doi: $10.12873 / 351$ honoriofransa

28. M. Costantino, A. Filippelli, C. Giampaolo, L. Tiano, D.M. Carlucci, V. Coiro and L. Rastrelli, Pharmacologyonline, 1 (2012) 220.

https://pharmacologyonline.silae.it/files/spec ialissues/2012/vol1/PhOL_2012_1_S025_C ostantino.pdf

29. O. Elkayam, I. Wigler, M. Tishler, I. Rosenblum, D. Caspi, R. Segal, B. Fishel and M. Yaron, J. Rheumatol., 18 (1991) 1799.

https://pubmed.ncbi.nlm.nih.gov/1795315/

30. M. Tishler, Y. Brostovski and M. Yaron, Clin. Rheumatol., 14 (1995) 21.

https://doi.org/10.1007/BF02208080

31. C. Vaamonde-García, Á. Vela-Anero, T. Hermida-Gómez, E. Fernández-Burguera, P. Filgueira-Fernández, N. Goyanes, F.J. Blanco and R. Meijide-Faílde, Int. J. Biometeorol., 64 (2020) 307. https://link.springer.com/article/10.1007/s00 484-019-01807-w

32. Ş. Şahin-Onat, Ö. Taşoğlu, Z. Özişler, F. D. Güneri and N. Özgirgin, Arch. Rheumatol., 30 (2015) 292.

https://doi.org/10.5606/ArchRheumatol.201 $\underline{5.5484}$

33. V. Tékus, É. Borbély, T. Kiss, A. Perkecz, Á. Kemény, J. Horváth, A. Kvarda and E. Pintér, Evid. Based Complement. Alternat. Med., 2018 (2018) 1. https://doi.org/10.1155/2018/4816905

34. A. Salami, M. Dellepiane, F. Strinati, L. Guastini and R. Mora, Rhinology, 48 (2010) 71. doi: 10.4193/Rhin09.065
35. M. Pellegrini, D. Fanin, Y. Nowicki, G. Guarnieri, A. Bordin, D. Faggian, M. Plebani, M. Saetta and P. Maestrelli, Respir. Med., 99 (2005) 748. https://doi.org/10.1016/j.rmed.2004.11.001

36. C. Carubbi, E. Masselli, E. Calabrò, E. Bonati, C. Galeone, R. Andreoli, M. Goldoni, M. Corradi, N. Sverzellati and G. Pozzi, Int. J. Biometeorol., 63 (2019) 1209. https://doi.org/10.1007/s00484-019-01737-7

37. L. Rapolienè, J. Adv. Med. Med. Res., 18 (2016) 1.

38. F. Cantalamessa and C. Nasuti, Nutr. Res., 23 (2003) 775.

https://doi.org/10.1016/S02715317(03)00033-2

39. Y. Zair, F. Kasbi-Chadli, B. Housez, M. Pichelin, M. Cazaubiel, F. Raoux and K. Ouguerram, Lipids Health Dis., 12 (2013) 105. https://doi.org/10.1186/1476-511X-12-105

40. P.-h. Subtavewung, M. Raksaskulwong and J. Tulyatid, in: Proceedings World Geothermal Congress, (2005) 7.

https://www.geothermalenergy.org/pdf/IGAstandard/WGC/2005/08 45.pdf

41. Z. Shi, F. Liao, G. Wang, Q. Xu, W. Mu and X. Sun, Geofluids, 2017 (2017). https://doi.org/10.1155/2017/6546014

42. Z. Hamzah, N. A. Rani, A. Saat and A. K. Wood, Malay. J. Anal. Sci., 17 (2013) 436. http://pkukmweb.ukm.my/ mjas/

43. J. J. Rowe, R. O. Fournier and G. W. Morey, Chemical analysis of thermal waters in Yellowstone National Park, Wyoming, 1960-65, US Government Printing Office, 1973.

https://www.osti.gov/biblio/5069943

44. C. Kusuda, H. Iwamori, H. Nakamura, K. Kazahaya and N. Morikawa, Earth Planets Space, 66 (2014) 119.

https://doi.org/10.1186/1880-5981-66-119

45. M. Anees, M. M. Shah and A. A. Qureshi, Procedia Earth Planet. Sci., 13 (2015) 291. https://doi.org/10.1016/j.proeps.2015.07.068

46. H. Baioumy, M. Nawawi, K. Wagner and M. H. Arifin, J. Volcano. L Geotherm. Res., 290 (2015) 12.

https://doi.org/10.1016/j.jvolgeores.2014.11. $\underline{014}$ 
47. M. Anees, M. Shah, A. Qureshi and S. Manzoor, Geologica Acta., 15 (2017). doi:10.1344/GeologicaActa2017.15.3.5

48. D. Oyuntsetseg, E. Uugangerel, A. Minjigmaa and A. Ueda, Mon. J. Chem., 15 (2014) 56.

https://doi.org/10.5564/mjc.v15i0.324

49. G. Bignair, B. Batkhishig and N. Tsuchiya, (2004).

50. A. Homma and H. Tsukahara, Bull. Earth. Res. Inst., Univ. Toky, 83 (2008) 217. http://www.eri.utokyo.ac.jp/BERI/pdf/IHO83208.pdf

51. S. Kele, A. Demény, Z. Siklósy, T. Németh, M. Tóth and M. B. Kovács, Sediment. Geol., 211 (2008) 53. https://doi.org/10.1016/j.sedgeo.2008.08.004

52. A.P. Verhagen, S.M. Bierma-Zeinstra, M. Boers, J. R. Cardoso, J. Lambeck, R. de Bie and H. C. de Vet, Cochrane Database Syst. Rev., (2004).

https://doi.org/10.1002/14651858.CD00051 $\underline{8}$

53. I. Ghersetich and T. M. Lotti, Clin. Dermatol., 14 (1996) 563.

https://doi.org/10.1016/S0738081X(96)00085-5

54. N. Altman, Healing springs: the ultimate guide to taking the waters, Inner Traditions/Bear \& Co, (2000).

http://www.mynimahellas.com/dsmap9/9780892818365 healing springs the ultimate guide to taking the waters abebooks altman nathaniel_08928 18360.pdf

55. S. Haydar and J.A. Aziz, J. Hazard. Mater., 163 (2009) 1076.

https://doi.org/10.1016/j.jhazmat.2008.07.07 $\underline{4}$
56. J. Eaton, in, (2004).

57. C. Gutenbrunner, T. Bender, P. Cantista and Z. Karagülle, Int. J. Biometeorol., 54 (2010) 495.

https://doi.org/10.1007/s00484-010-0321-5

58. S. Quattrini, B. Pampaloni and M.L. Brandi, Clin. Cases Miner. Bone Metab., 13 (2016) 173. doi: $10.11138 / \mathrm{cmbm} / 2016.13 .3 .173$

59. S. Tenti, S. Cheleschi, M. Galeazzi and A. Fioravanti, Int. J. Biometeorol., 59 (2015) 1133. https://doi.org/10.1007/s00484-014-0913-6

60. L. C. Parish and J. A. Witkowski, J. Eur. Acad. Dermatol. Venereol., 3 (1994) 465. https://doi.org/10.1111/j.14683083.1994.tb00401.x

61. J. M. Carbajo and F. Maraver, Evid-Based Complement. Alternat. Med., 2017 (2017). https://doi.org/10.1155/2017/8034084

62. T. Bender, G. Bálint, Z. Prohászka, P. Géher and I.K. Tefner, Int. J. Biometeorol., 58 (2014) 311. https://doi.org/10.1007/s00484-013-0667-6

63. L. Xu, R. Shi, B. Wang, Y. Gao, J. Geng, L. Zhou, G. Guo, Y. Zhang, J. Chen and X. Cao, J. Phy. Ther. Sci., 25 (2013) 51. https://doi.org/10.1589/jpts.25.51

64. A. P. Verhagen, S. Bierma-Zeinstra, M. Boers, J. R. Cardoso, J. Lambeck, R. de Bie and H.C. de Vet, The Cochrane Library, (2007). https://doi.org/10.1002/14651858.CD00334 $\underline{3 . p u b 3}$

65. J. Naumann and C. Sadaghiani, Arthritis Res. Ther., 16 (2014) R141. https://doi.org/10.1186/ar4603 